Diana-Urania Galetta, Access to administrative documents and to public sector information in Italy, in R. Perlingeiro, H-J. Blanke (Eds.), The Right of Access to Public Information. An International Comparative Legal Survey, Springer, Heidelberg-Dordrecht-London-New York, 2018, ISBN 978-3-662-55552-1, pp. 343-367

Keywords: Right of Access; Privacy Protection; Transparency; Open Data Policy; Public Access; Impartiality; Public sector information; Prevention of corruption; Institutional website; Transparent Administration; Accountability; Italian APA; Italian FOIA; Transparency-on-request; National Anti-Corruption Authority

\title{
ACCESS TO ADMINISTRATIVE DOCUMENTS AND TO PUBLIC SECTOR INFORMATION IN ITALY \\ Diana-Urania Galetta ${ }^{1}$
}

Table of content

1 Introduction

2 The Right of Access to Administrative Documents in Italian Law No. 241/90 on Administrative Procedure

2.1 Origin and Nature of the Right of Access

2.2 Ownership and Formalities for Exercising the Right of Access

2.3 Subject and Scope of the Right of Access

2.4 Restrictions to the Right of Access

2.5 Right of Access and Privacy Protection

2.6 Protection of the Right of Access

3 Transparency and Access: Between National Law and European Union Law

3.1 Lack of Connections between the Right of Access pursuant to Law No. 241/90 and Transparency, and Discrepancies with the European Union Law

3.2 Transparency as an "Open Data Policy": From Legislative Decree No. 150/2009 to Legislative Decree No. 33/2013

3.3 Implementation of Transparency Rules: The Transparency Officer, Sanctions, and Public Access (accesso civico)

4 The latest stage of the Italian journey towards transparency. "Law Madia" and the Italian FOIA: designing the new "public access era" in Italy?

4.1 Transparency as freedom of access to the data and documents held by public authorities

4.2 Restrictions to public access and the role of the Anti-Corruption Authority

5 Conclusions

\section{Introduction}

Law No. 241 of 1990 on administrative procedure (Italian APA) established general rules on the right of access to administrative documents for the first time in the Italian legal system, ${ }^{2}$ which

\footnotetext{
1 This paper is part of the publications related to project PRIN 2012 (2012SAM3KM) on Codification of EU Administrative Procedures. All translations from Italian contained in this paper are mine, unless otherwise indicated. Last update: December 2016. ${ }^{2}$ Law No. 241 of 11 August 1990 setting new rules concerning administrative procedure and the right of access to documents, published in the Official Gazette of 18 August 1990, No. 192.
} 
partly reproduce rules defined in sectorial legislations.

Law No. 241/90 was the first concrete and organic attempt by the Italian legislator to implement the principles laid down in the first paragraph of Art. 97 of the Constitution, according to which public bodies are organized in such a way as to ensure good administration and impartiality.

Nevertheless, fifteen years later, with Law No. $15 / 2005,{ }^{3}$ the Italian Parliament re-wrote almost the entire Chapter V of Law No. 241/90 on access to administrative documents and made some steps back, insofar as access to administrative documents is concerned.

At the same time, in 2006 a Legislative Decree (No. 36/2006) ${ }^{4}$ was adopted in order to transpose Directive 2003/98/EC ${ }^{5}$ on the re-use of public sector information.

Although the aim of this Directive was only to establish a minimum set of rules governing the re-use (for private or commercial purposes) of existing documents held by public bodies of the Member States, and although the Directive aimed at building on the existing access regimes in the Member States, without changing the national rules on access to documents, ${ }^{6}$ it did represent a starting point for the adoption of open data policies in many Member States, including Italy. In fact, while it merely aimed at providing a minimal harmonization and did not pose any obligation to allow re-use of documents, de facto it encouraged a broader availability of public sector information with the idea that such an extended availability would represent some sort of added value also for the public body itself, by promoting transparency and accountability. ${ }^{7}$

Following this Open Data Policy trend, in 2009 and in 2013 the Italian Government adopted two legislative decrees bearing the paradigmatic headings: "Optimization of productivity of public work and efficiency and transparency of the public administration" (legislative decree No. $150 / 2009^{8}$ ) and "Reorganization of the rules concerning the obligations of publicity, transparency and dissemination of information by public authorities” (legislative decree No. 33/2013 ${ }^{9}$ ).

\section{The Right of Access to Administrative Documents in Italian Law No. 241/90 on Administrative Procedure}

\subsection{Origin and Nature of the Right of Access}

The general discipline on the right of access to administrative documents, which in Italy was defined for the first time under Chapter V of Law No. 241/1990 setting new rules concerning administrative procedure and the right of access to documents, ${ }^{10}$ is the result of a long and complex development process.

The Report of the Constituent Assembly, which was submitted to the Investigation Commission set up by order of the Prime Minister on 11 October 1944, already pointed out that a general law on the public administration was required in order to regulate, amongst other things, the possibility for citizens to view and obtain copies of administrative documents in order to «counter

\footnotetext{
${ }^{3}$ Law No. 15 of 11 February 2005 that introduces Amendments to Law No. 241 of 7 August 1990, relating to general rules on administrative action, published in the Official Gazette of 21 February 2005, No. 42

${ }^{4}$ Legislative Decree No. 36 of 24 January 2006, published in the Official Gazette of 14 February 2006.

${ }^{5}$ Directive 2003/98/EC of the European Parliament and Council of 17 November 2003 on the re-use of public sector information, at http://www.eurlex.eu. Directive 2003/98/EC was recently amended by Directive 2013/37/EU of the European Parliament and Council of 26 June 2013, at http://www.eurlex.eu.

${ }^{6}$ Directive 2003/98/EC quoted above, recital No. 9.

${ }^{7}$ See now Directive 2003/98/EC as amended by Directive 2013/37/EU quoted above, recital No. 4.

${ }^{8}$ Legislative Decree No. 150 of 27 October 2009, published in the Official Gazette of 31 October 2009, No. 254.

${ }^{9}$ Legislative Decree No. 33 of 14 March 2013, published in the Official Gazette of 5 March 2013, No. 80.

${ }^{10}$ Quoted above, note No. 2.
} 
the bad habit prevailing in the public administration to hinder such knowledge.» ${ }^{11}$ However, the scheme of the aforementioned general law designed by the Forti Commission did not receive the expected support, as was the case with the following bills presented in 1954 and in 1955, and the bills in Parliament submitted during the same period and later re-submitted in $1963 .{ }^{12}$

After several failed attempts made in the previous decades, at the beginning of the 1980's increasingly pressing requests were made to issue a whole series of general rules governing the administrative procedure, reflecting what had recently happened in Germany with the introduction of the Verwaltunsgverfahrensgesetz in 1976. As a result, a new commission chaired by Professor Mario Nigro ${ }^{13}$ was appointed, which concluded its work in 1984. The commission prepared two different law drafts: one on the administrative procedure and one on the right of access to administrative documents. The documents in point were then unified and, together, were formalized into Law No. 241/90 under the heading « New rules concerning administrative procedure and the right of access to documents».

As will be described below (section 2.3, along with subsequent sections), under Law No. 15/2005, Chapter V of Law No. 241/90 on access to administrative documents was later re-written almost entirely.

Before Law No. 241/90 was passed, the right of access to administrative documents had already been established - specifically as from the beginning of the 1980's - by several sectorial legislations. ${ }^{14}$ However, the Italian legal theory had long identified sound constitutional grounds on which a general right of access to the public administration documents could be based. Such grounds included, first and foremost, the principles of democracy, protection of personal rights, and equality set under Art. 1, 2, and 3 of the Constitution; secondly, the general guarantee of those freedoms that provide a democratic connotation to the citizen/authority relationship, most notably the freedom of information, which is guaranteed under Art. 21 of the Constitution, but more than that, by the entire Italian Constitution. ${ }^{15}$ This right to information is, in turn, also a result of the provisions of Art. 97 and 98 of the Constitution. ${ }^{16}$ Further constitutional grounds supporting access to administrative documents are to be found also in Art. 24 and 113 of the Constitution due to the broader guarantee that the right of access to administrative documents provides to the judicial protection of the rights and interests set forth therein. ${ }^{17}$

After Law No. 241/90 was passed, the legal theory agreed that, with the provisions on the right of access set forth under Art. 22 of Law No. 241/90, the principle of secrecy in administrative activities had finally been overturned in favor of the opposite principle of transparency. ${ }^{18}$ Indeed, in its original version, Art. 22 of Law No. 241/90 explicitly provided that "[i]n order to ensure transparency in the administrative activities and to facilitate impartiality thereof, anyone who may be interested therein for the protection of legally relevant situations is granted the right to access administrative documents pursuant to the formalities established under this law." However, in the years following the introduction of the above-mentioned legislation, a restrictive interpretation

\footnotetext{
${ }^{11}$ Quoted in Cuocolo 1995, p. 527.

12 See Pastori 1986, p. 49 et seq.; Selleri 1989, p. 359 et seq.

13 Leading exponent of the Italian legal theory on administrative law for many decades. For information visit http://www.treccani.it/enciclopedia/mario-nigro_\%28Enciclopedia_Italiana\%29/. Accessed 10 June 2014.

${ }^{14}$ For a general overview of the previous sectorial legislation on this topic: Sandulli, M.A., 2000, paragraph 3.

${ }^{15}$ See Selleri 1984, p. 24

${ }^{16}$ Morbidelli 2005, passim.

${ }^{17}$ Sandulli, M.A., 2000, paragraph 2.

${ }^{18}$ See Sandulli, A., 1998, p. 535, who underlines the overcoming of the idea of secrecy as a subjective predicate (a document is secret just because it is of the public administration), for a transition to a concept of secrecy as an objective requirement of the document, rather related to the substance of the information contained therein.
} 
approach began to widespread commonly in court rulings, ${ }^{19}$ aimed at equating the interest to gaining access to administrative documents to the so-called interest to bring a legal action. The consequence of this was that the applicant was required to provide evidence of a direct, concrete, and actual interest to access administrative documents as is required, in the Italian system of administrative judicial protection, of anyone who wants to bring a legal action. ${ }^{20}$

Later on, the new legislation introduced in $2005^{21}$ radically changed the provision of Art. 22 of Law No. 241/90 and adopted this restrictive interpretation established in court rulings. This meant that, on that occasion, transparency was expunged from the right of access ${ }^{22}$ and included in Art. 1 of Law No. 241/90, i.e. the Article setting the general principles for the administrative activities. ${ }^{23}$ In essence, as from 2005, pursuant to the general rules established under Art. 22, the exercise of the right of access was explicitly limited to "private parties, including stakeholders representing public or widespread interests, who have a direct, concrete, and actual interest corresponding to a legally protected situation that is linked to the document to which access is requested." 24

As a complement to such restrictive provision, Art. 24.3 of Law No. 241/90 (also introduced with the new provisions of Law No. 15/2005) explicitly provides that "no requests of access made with the intention of generally monitoring the work of public administrative bodies shall be accepted."

As to the nature of the right to access, while in the European Law the nature of such access is that of a proper right to citizenship, ${ }^{25}$ in the Italian legal system the nature of such access is still debated, both in court rulings and in the legal theory.

While some authors, making reference to the literal meaning (right of access) and to other elements (e.g. exclusive jurisdiction of the administrative court), consider it to be a subjective right, ${ }^{26}$ others, focusing on different elements (judicial protection entrusted to the administrative court, request subject to the discretionary approval of the administration), speak of a mere legitimate interest. ${ }^{27}$ And therefore of an individual subjective legal position which undoubtedly is less protected and largely ancillary to the protection of public interest. ${ }^{28}$ Incidentally, this understanding of the right of access as a mere legitimate interest is also supported in the rulings of the Italian Council of State. ${ }^{29}$

\subsection{Ownership and Formalities for Exercising the Right of Access}

\footnotetext{
${ }^{19}$ Italian Council of State, IV, 10 June 1996, No. 1024; VI, 7 December 1993, No. 966; VI, 19 July 1994, No. 1243; IV, 26 November 1993, No. 1036. See also Gallo \& Foà 2000, p. 6 et seq.

${ }^{20}$ Villata 1989, p. 3.

${ }^{21}$ Quoted above, note No. 3.

${ }^{22}$ See Carloni 2009, passim. See infra, paragraph 3.1.

${ }^{23}$ Pursuant to Art. 1 of Law No. 241/90, in the version amended in 2005, "Administrative activities shall pursue the objectives established by the law and shall be governed by the criteria of economy of action, effectiveness, impartiality, publicity and transparency, in accordance with the formalities laid down both in this law and in the other provisions governing individual procedures, as well as by the principles established in the legal order of the European Community."

${ }^{24}$ Art. 22, paragraph 1b of Law No. 241/90.

${ }^{25}$ Court of First Instance, 17 June 1998, in Case T-174/95, Svenska Journalistförbunde v. Council, in ECR, 1998, p. II-2289 et seq.

${ }^{26}$ See Figorilli 1995, p. 598 et seq. ; Perini 1996, p. 109 et seq.

${ }^{27}$ See Paleologo 1991, p. 12; Morbidelli 1998, p. 1310 et seq.; Mazzarolli 1998, p. 58 et seq.

${ }^{28}$ According to the Italian legal theory on administrative law, a "legitimate interest" is an individual interest that is closely connected to a public interest and protected by the law only through the legal protection of the latter. For an introduction to Italian Public Law, see Ferrari 2008.

${ }^{29}$ Italian Council of State , V, 2 December 1998, No. 1725 confirmed by a later decision of the plenary session of 24 June 1999 , No. 16.
} 
As anticipated in the previous section, the right of access is now granted - pursuant to Art. 22 c. 1 letter b) of Law No. 241/90 - only to the stakeholders, who are to be understood as "all private parties, including stakeholders representing public or widespread interests, who have a direct, concrete, and actual interest corresponding to a legally protected situation that is linked to the document to which access is requested." As was discussed above, the new provision seems to be more restrictive than the original one established under Art. 22, but it fully reflects not only the position that has gradually gained consensus in the court rulings, but also a typical tradition of the Italian administrative system that, starting from the unification of Italy, has always been based on the principle of confidentiality of information, ${ }^{30}$ which was a binding duty of civil servants who were obliged to keep the strictest confidentiality on all information that they became aware of in the performance of their working tasks, as a result of an authoritative and all but transparent model of public administration. ${ }^{31}$

However, the provisions of Art. 22 in its currently applicable version do not prevent the possibility to introduce a broader right of access in special sectorial legislations. This is the case, for instance, of Legislative Decree No. $195 / 2005^{32}$ on the environment, which makes environmental information available to anyone who applies for it, with no need to state or qualify his or her interest. Another example is offered by the consolidated law on local government agencies, ${ }^{33}$ where Art. 10, in addition to granting citizens the right to access information to acts and proceedings that directly involve them, recognizes the right to access "the information held by the administration in general." ${ }^{34}$ However, the prevailing interpretation of this legislation in the court rulings is extremely restrictive as, in this case too, it requires evidence of a specific interest in the document in point. ${ }^{35}$

As to the formalities for exercising the right of access, pursuant to Art. 22 c. 1 letter a) of Law No. 241/90, the right of access is to be understood as "the right of interested parties to view and to take copies of administrative documents."

Pursuant to the provisions of Presidential Decree No. 184/2006, ${ }^{36}$ access may be both informal, "upon request, including a verbal request" (Art. 5), and formal, "[s]hould it not be possible to immediately fulfil the request informally, or should there be doubts on the title of the applicant, his/her identity or power of representation, or on the actual interest based on the supplied information or documents, on the accessibility to the document or on the existence of other interested parties" (Art. 6).

In both cases, the request of access must be duly motivated so as to show the qualified interest that is now necessarily required in order for the right of access to be granted.

In the case of informal access, "the request is examined immediately, is subject to no

\footnotetext{
${ }^{30}$ Pursuant to Section 15 of the Consolidated Law on civil servants approved by Presidential Decree No. 3 of 10 January 1957 : "Employees must keep full confidentiality on their civil service. They shall not disclose information regarding administrative measures or operations, whether ongoing or completed, or information that has come to their knowledge by virtue of their duties, to persons who are not entitled to it, except in the situations and in the ways provided for by the rules governing the right of access. Within their individual fields of competence, employees who are responsible for an office shall issue copies and excerpts from official instruments and documents only in those cases that are not prohibited by the internal rules of the office.”

${ }^{31}$ Arena 1984, passim.

${ }^{32}$ Legislative Decree No. 195 of 19 August 2005, "Implementation of Directive 2003/4/EC on public access to environmental information,” published in the Official Gazette of 23 September 2005, No. 222.

${ }^{33}$ Legislative Decree No. 267 of 18 August 2000, “Consolidated law on local government,” published in the Official Gazette of 28 September 2000, No. 227.

${ }^{34}$ Back in the pre-Republican time, citizens were entitled to view and obtain copies of all the resolutions taken by municipalities and provinces under Art. 62 of the consolidated provincial and municipal laws. See Sandulli, M.A., 2000, paragraph 1.

${ }^{35}$ For general reference, see Italian Council of State V, No. 1412 of 18 March 2004, at http://www.giustizia-amministrativa.it.

${ }^{36}$ Presidential Decree No. 184 of 12 April 2006, "New regulations on access."
} 
formalities, and is deemed to be approved by the act of indicating the publication containing the relevant information, or showing the relevant document, or making copies, or any other suitable act." ${ }^{37}$ Conversely, in the case of formal access, "the access procedure must be concluded within a term of 30 days." ${ }^{38}$ Within ten days, the administration may suspend the term should it be necessary to supplement the documentation that turned out to be irregular or incomplete. ${ }^{39}$

The act, whereby a formal request of access is approved, is an administrative decision proper and in all respects. Such administrative act "always comes with the indication of the office and the branch to which reference can be made, as well as with an appropriate period of time of no less than 15 days in which the relevant documents can be viewed or copies thereof can be obtained." 40 The documents must be viewed at the office indicated in the request approval administrative decision, during the working hours, before the staff in charge, if necessary. ${ }^{41}$

Finally, pursuant to the provisions of Art. 25 of Law No. 241/90, “[t]he right of access shall be exercised by viewing and taking copies of the relevant administrative documents, in the ways and subject to the limitations established under this law. Document viewing is subject to no charge. Without prejudice to the provisions currently in force on stamp duties, as well as (re)search and survey rights, the issuance of a copy shall be subject only to payment of the copying costs incurred into." Therefore, no document can be taken away or altered in any manner. In addition to asking for copies of such documents subject to payment of the relevant copying costs, the person in point will only be allowed to take notes and transcribe the viewed documents in full or part thereof.

\subsection{Subject and Scope of the Right of Access}

Pursuant to the provisions of Art. 22 letter d), as amended by Law No. 15/2005, "administrative documents include ... every graphic, photographic or filmed, or electromagnetic or any other kind of representation of the contents of acts, including internal documents or those not relating to a specific procedure, that are held by a public administrative body and concern activities of public interest, regardless of whether the substantive law governing them is public or private law."

In addition to confirming that access is granted also with reference to a pending administrative procedure and, hence, the right can be exercised also on documents that are still internal to the administration (the so-called "access during the course of the procedure"), the aforementioned provision now points out that the right is also granted on documents that do not relate to a specific administrative procedure (the so-called informative access or "access outside of the course of the procedure.") ${ }^{42}$ This confirms that the scope of the right of access is broader than that of the administrative procedure. ${ }^{43}$

As to the scope of the right of access, Art. 23 of Law No. 241/90 points out that the right of access may be exercised vis à vis administrative bodies, autonomous and special corporations, public bodies, and private parties operating public services. The right of access vis à vis independent regulatory and supervisory authorities shall be exercised within the framework of their respective regulations, in accordance with the provisions of Art. 24 of Law No. 241/90.

\footnotetext{
${ }^{37}$ Art. 5.3 of Presidential Decree No. 184/2006.

${ }^{38}$ Art. 6.4 of Presidential Decree No. 184/2006.

${ }^{39}$ Art. 6.5 of Presidential Decree No. 184/2006.

${ }^{40}$ Art. 7.1 of Presidential Decree No. 184/2006.

${ }^{41}$ Art. 7 of Presidential Decree No. 184/2006.

42 See also Sandulli, M.A., 2000, para 4 and 5.

${ }^{43}$ Falcon 2008, passim.
} 
In this regard, it should also be pointed out that, while access is granted to all acts when it comes to public administrative bodies, including those governed by the private law, ${ }^{44}$ when it comes to private parties, access to their activities is granted only limited to those that are of public interest and all other activities that may be instrumental thereto. In this respect, the courts ruled that, for example, the documents relating to staff enrolment for "Ente Poste s.p.a." could be accessed since they are instrumental to managing a service of public interest. ${ }^{45}$

The same remarks apply to economic public bodies.

\subsection{Restrictions to the Right of Access}

Pursuant to Art. 25.3, of Law No. 241/90, “Access may be denied, postponed, or restricted in the cases and to the extent established under Art. 24. The reasons for such denial, postponement or restriction must be stated."

Art. 24 then lists a number of cases in which access to documents is excluded, namely: a) documents under State secret; b) tax proceedings, which remain governed by specific rules applicable to them; c) those activities of the public administration that are aimed at issuing regulatory, general administrative, planning, and programming documents, which remain governed by specific rules applicable to their finalization; d) selection procedures, in relation to administrative documents containing psycho-aptitude information on third parties.

Art. 24.5 further specifies that documents containing information connected to the interests referred to in paragraph 1 of the same Article "shall be deemed secret solely within the limited scope of such connection" and that "to such end, if applicable, the public administrative authorities shall also establish, for each category of documents, the timeframe during which the right of access shall not be granted." However, paragraph 6 of the same Article provides that the Government may establish, via a regulation, other cases in which administrative documents shall not be accessible in order to protect one of the interests set forth therein (national security and defense, international relations, monetary and currency policies, protection of the public order, documents relating to the private life or confidentiality of third parties, etc.).

However, access is only denied as a last resort, namely "Access to administrative documents cannot be denied in cases in which it suffices to resort to the power of deferment." 46

\subsection{Right of Access and Privacy Protection}

The most delicate issue regarding accessibility of documents is undoubtedly the relationship between the right of access and privacy protection. This issue was firstly solved via the interpretations given in the legal theory and court rulings, ${ }^{47}$ and later was formally regulated by the novel provisions of Law No. 15/2005.

In this specific regard, the new paragraph 7 of Art. 24 states that whereas, on the one hand, access has to be guaranteed to those administrative documents whose knowledge is necessary in order to protect or defend legal interests (see indent 1), on the other hand (see indent 2) "[i]n the case of documents containing sensitive or judicial data, access shall be permitted to the extent that it

\footnotetext{
${ }^{44}$ Italian Council of State, plenary section, Decision of 22 April 1999, No. 4, Giornale di Diritto amministrativo, 1999 , p. 946.

45 Italian Council of State, VI, Decision of 5 March 2002, No. 1303, at http://www.giust.amm.it.

${ }^{46}$ Art. 24.4.

${ }^{47}$ For further details, see Sandulli, M.A, 2000, para 8.
} 
is strictly indispensable and within the terms established under Art. 60 of Legislative Decree No. 196 of 30 June 2003, in the case of data that might reveal information on health conditions and sexual life."

However, the court rulings seem to take a wavering position on the issue of the actual balance between access and privacy. As a matter of fact, extremely difficult and delicate comparative evaluations need to be made, which require "an accurate assessment to be made on a case by case basis as to the legal situations that are to be taken into consideration from time to time." 48 In light thereof, the solution seems to lie in the "limitation" of access referred to in Art. 25.3 (in addition to the cases of denial and deferment). Such limitation - as the court rulings point out - may well consist in using, if necessary, "the wording "omissis/omitted" to replace the information that fall under the protection of the right to privacy. ${ }^{49}$

\subsection{Protection of the Right of Access}

Pursuant to Art. 4.25, also amended by Law No. 15/2005, "Upon expiry of a thirty-day term as from the date of the request without any successful result, such request shall be deemed rejected." This is namely a case of the so-called "silence-denial."

When faced with a decision to explicitly or implicitly deny access or with the postponement thereof, two options can be pursued in accordance with Art. 25.4: one is to appeal to the Italian Administrative Tribunal (Tribunale amministrativo regionale - TAR), which decides following a special "ruling in chambers" within thirty days as from the expiry of the term established for lodging an appeal and after hearing the defense counsels, if thus requested by the parties. The decision of the Administrative Tribunal is not temporary or preparatory to any other judgment. Indeed, it settles the dispute and can be appealed, within thirty days as from the date of notification, to the Council of State, which will decide on the appeal following the same procedure and within the same timeframe as the Administrative Tribunal.

The second alternative option offered by Art. 25.5, is to appeal to the Ombudsman with competence in that territorial jurisdiction if the matter is related to official documents of local, provincial, or regional administrations, or to the Commission for Access - referred to in Art. 27 - if the case concerns official documents of the central and de-centralized state administrative bodies. In both cases the appeal will consist in asking for a reversal of the decision concerning access to documents taken by the administration responsible for granting access.

Should the thirty-day term for the decision on the appeal expire without any decision being taken, the appeal shall be deemed to be rejected (Art. 24.4).

Conversely, should the Ombudsman or the Commission for Access deem the denial or the postponement of access to documents to be unlawful, "they shall inform the applicant and notify the authority responsible for granting access thereof." Should the latter "fail to issue an act confirming and stating the reasons for its decision within thirty days as from receipt of the notification by the Ombudsman or the Commission, access shall be granted."

Special rules apply, however, if access is denied or postponed due to reasons concerning personal data referring to third parties. In such case, the Commission for Access shall decide upon prior consultation with the Data Protection Supervisor, which shall issue its opinion within ten days as from the request and which opinion shall be deemed to have been given, should such period of

\footnotetext{
${ }^{48}$ Italian Council of State, V, 28 September 2007, No. 4999.

${ }^{49}$ Italian Council of State, V, 28 September 2007 quoted.
} 
time expire unsuccessfully.

Pursuant to the last indent of Art. 25.5, all disputes concerning access to administrative documents shall submitted to the exclusive jurisdiction of the administrative judge. It is further pointed out that "in trials concerning access, the parties may act in person without the aid of a counsel" and that "the administrative authority may be represented and defended by one of its own employees, provided that the latter fulfills an executive role and that he/she has been authorized to do so by the legal representative of the administrative body in point." 50

As the decision of the administrative judge is concerned, "it shall order the production of the requested documents, provided that the applicable conditions are fulfilled." 51

\section{Transparency and Access: Between National Law and European Union Law}

\subsection{Lack of Connections between the Right of Access pursuant to Law No. 241/90 and Transparency, and Discrepancies with the European Union Law}

The European Union law recognizes a fundamental connection between transparency, good governance, and right of access to public documents. The existence of such connection emerges quite clearly from several speeches that the first European Ombudsman, Mr. Jacob Söderman, delivered specifically on these issues. ${ }^{52}$

These concepts are also dealt with in the Treaty of Rome as recently amended by the Treaty of Lisbon, which entered into force on 1 December 2009. As a matter of fact, Art. 15.1, of the Treaty on the Functioning of the European Union (TFEU), provides that "In order to promote good governance and ensure the participation of civil society, the Union institutions, bodies, offices, and agencies shall conduct their work as openly as possible.” Then, paragraph 3 reiterates the provisions of old Art. 255 TEC, according to which "Any citizen of the Union, and any natural or legal person residing or having its registered office in a Member State, shall have a right of access to documents of the Union institutions, bodies, offices, and agencies, whatever their medium ..."53

In this respect, till the adoption of the recent FOIA Decree (see infra, para. 4), there was a clear discrepancy between the approach chosen by the Italian legislator and the approach adopted by the European Union. As the Italian APA restricted access to all acts and documents - including the internal records - by means of which the administrative function is carried out, and while the latter is being carried out, only to those persons who have a legitimate title thereto and have an interest therein for the protection of their title. ${ }^{54}$ Therefore, in the Italian legal system the right of access to document provided for by Italian APA (to be clearly distinguished from the new "public access" - accesso civico - provided for by the Italian FOIA - see infra, para. 4) is basically understood as a form of guarantee given specifically to those subjects, with the specific purpose of putting them, through a more comprehensive representation of the factual and legal situation that they have a more direct interest in, in a position to best exercise the rights - of participation and/or objection - that the legal system grants to them for the protection of their title, thus only indirectly enhancing - also and mainly through their involvement in the administrative procedure - the impartiality of the administrative action. The goal of transparency in the administrative action,

\footnotetext{
${ }^{50}$ Art. 25.5-bis (also introduced by Law 15/2005).

${ }^{51}$ Art. 25.6.

${ }^{52}$ Galetta 2006, passim.

${ }^{53}$ See also Ziller 2014, passim.

${ }^{54}$ See above, par. 2.1.
} 
while stated in general terms in Art. 22.2 of Law 241/90, ${ }^{55}$ is thus guaranteed only in special circumstances and with extremely weak effects on administrative impartiality.

As a matter of fact, the only element that really reflects the principle of transparency, which is to be found in the context of Law No. 241/90, does not relate to the right of access to documents of the administration, but to the much more limited duty to publish "directives, programmes, instructions, circulars and every act that, in general, poses requirements for the organisation, functions, goals, and procedures of a public administrative authority, or which establishes the interpretation of legal rules, or provides for their implementation.” 56

\subsection{Transparency as an “Open Data Policy”: From Legislative Decree No. 150/2009 to Legislative Decree No. 33/2013}

After the first approach in 2006, ${ }^{57}$ with a legislation adopted to transpose Directive 2003/98/EC ${ }^{58}$ on the re-use of public sector information, the first concretization of the principle of transparency in the Italian system was represented by the rules contained in in the so-called Brunetta Decree No. 150/200959, "Implementation of Law No. 15 of 4 March 2009 on the optimization of the productivity of public work and the efficiency and transparency of the public administration," 60 whose objectives include "transparency of the public administrations also as a guarantee of lawfulness” (Art. 2.2).

Art. 11 of the Brunetta Decree points out that "transparency has to be understood as full accessibility, including by publishing information on the institutional websites of the public administration bodies.” This provision generates a qualified legal position for each and every citizen who is now entitled to obtain public information, which, unlike the provisions that apply to the right of access to public acts, ${ }^{61}$ is patently aimed "at fostering widespread forms of monitoring so as to make sure that the principles of efficiency and impartiality are complied with" (Art. 11.1).

As far as the pursued goals are concerned, transparency - as regulated by the legislator in 2009 - can be considered to be aimed at two main goals, i.e. the efficiency of the public administration, which is pursued through the transparency of the performance of the administration and of public services, and prevention of corruption, which is pursued through the transparency of the procedure and of the organization. ${ }^{62}$

The second goal is actually the focus of the subsequent Legislative Decree No. 33/2013,

\footnotetext{
${ }^{55}$ According to Art. 22.2, introduced by law No. 69/2009, "In light of its important goals of public interest, access to administrative documents shall constitute a general principle governing administrative activity with the aim of fostering participation and of guaranteeing its impartiality and transparency.”

${ }^{56}$ Art. 26.1, of Law No. 241/90.

${ }^{57}$ Legislative Decree No. 36 of 24 January 2006, published in the Official Gazette of 14 February 2006.

${ }^{58}$ Directive 2003/98/EC of the European Parliament and Council of 17 November 2003 on the re-use of public sector information, at http://www.eurlex.eu. Directive 2003/98/EC was recently amended by Directive 2013/37/EU of the European Parliament and Council of 26 June 2013, at http://www.eurlex.eu.

${ }^{59}$ Renato Brunetta was Minister for Public Administration and Innovation from 2008 until 2011, during the fourth Berlusconi's Government.

${ }^{60}$ Legislative Decree No. 150 of 27 October 2009, quote.

${ }^{61}$ See above par. 2.1, where a reference is made to Art. 24.3, according to which "no request of access made with the intention of generally monitoring the work of public administrative bodies shall be accepted.” On this specific point see Patroni Griffi 2013, para 2.

${ }^{62}$ In accordance with the provisions of Art. 9 of the United Nations Convention against corruption, stating that "taking into account the need to combat corruption, each State Party shall, in accordance with the fundamental principles of its domestic law, take such measures as may be necessary to enhance transparency in its public administration, including with regard to its organization, functioning and decision-making processes, where appropriate”. https://www.unodc.org/documents/treaties/UNCAC/Publications/Convention/08-50026_E.pdf. Accessed on 10 June 2014.
} 
whose specific aim - pursuant to law No. 190/2012 - is to prevent and eradicate illegality in the Public Administration.

More specifically - according to the first version of this Decree (amended by the Italian FOIA - see infra para. 4) public administration authorities were obliged to comply with the transparency requirements set forth in Decree No. 33/2013 and applicable to all of their activities, mainly by using the "institutional website" of each individual administration as a privileged instrument.

Indeed, any user may access such website to look for any information regarding the activity and the organization of the public bodies without having to go through an authentication process or being identified in any manner. The aforementioned information must be published on the home page of the institutional websites in the section on "Transparent Administration" and the Decree forbids the setting up of any filter and/or other technical device "aimed at preventing web-based search engines from indexing and searching this section”.

Specific limitations to transparency were defined with a view to guaranteeing some balance between the transparency obligation and the need to protect privacy. Indeed, full accessibility is excluded for sensitive and legal data. ${ }^{63}$ On the other hand, exceptions to transparency are admitted also in cases of public grants allotted to specific categories of beneficiaries due to their critical personal conditions - including economic, family and health-related situations - since disclosing such information would imply a severe, patent, and unjustified violation of personal or even sensitive data. ${ }^{64}$

\subsection{Implementation of Transparency Rules: the Transparency Officer, Sanctions, and Public Access (accesso civico)}

Pursuant to the explicit provisions of Legislative Decree No. 33/2013, public administrations shall have to guarantee the quality of the information published on the institutional websites in compliance with the duty of disclosure established by the law, ensuring that such information is intact, currently updated, comprehensive, timely, user-friendly, easily understandable, easy to access, true to the original documents held by the administration, and indicating its origin and reusability. ${ }^{65}$

The transparency officer is the key subject, which was instituted ex novo under Decree No. $33 / 2013$, in charge of monitoring that the public administrations comply with the applicable provisions. ${ }^{66}$ The duties of this subject include the obligation to update the three-year plan for the prevention of corruption ${ }^{67}$ - which also provides specific monitoring measures on the fulfilment of transparency duties and further measures and initiatives aimed at promoting transparency - and to report any failure or delay in complying with the disclosure duties to the policy-making body, the Independent Assessment Body (Organismo indipendente di valutazione - OIV), the National AntiCorruption Authority, and, in the most severe cases, the disciplinary office.

In this regard, section VI of Legislative Decree No. 33/2013, which governs the supervision of the implementation of provisions and sanctions, is particularly important. Indeed, the Italian

\footnotetext{
${ }^{63}$ Referred to in Art. 4.1, letters d) and e) of Legislative Decree No. 196 of 30 June 2003. See also Art. 4 of Legislative Decree No. $33 / 2013$ in its original version (now Art. 7-bis).

${ }^{64}$ Art. 26.4 of Legislative Decree No. 33/2013, which has remained unchanged.

${ }^{65}$ Art. 6 et seq. of Legislative Decree No. 33/2013.

${ }^{66}$ See Art. 43 of Legislative Decree No. 33/2013.

67 The "Three-Year Programme for transparency and integrity" in the original version of Art. 46 et seq. of Legislative Decree No. $33 / 2013$.
} 
legislator was stricter here than it was in the past as it introduced sanctions in case of failure to comply with the applicable rules, which provide for disciplinary, management, and administrative responsibilities, as well as the application of administrative sanctions, publication of the relevant measures, and cancellation of resources previously allocated to agencies or bodies. ${ }^{68}$

The applicable sanctions apply both to the transparency officer, with reference to his/her specific duties, and to the managers of the Public administration and political bodies that are required to supply data in order to finalize the publication. In addition to the sanctions that are applicable to individual subjects, there are sanctions that are applicable to the relevant administrative decision, thus making it ineffective. ${ }^{69}$

A remarkably peculiar sanction is that of the so-called public access (accesso civico), which was established already under the original Art. 5 of the Decree and which has undergone substantial changes through the Italian FOIA (see infra para. 4). This provision explicitly stated that "the obligation established under the legislation in force for the public administration to publish documents, information, or data implies the right for anyone to request such documents, information or data in case of failure to publish them."70

\section{The latest stage of the Italian journey towards transparency. "Law Madia" and the Italian FOIA: designing the new "public access era” in Italy?}

\subsection{Transparency as freedom of access to the data and documents held by public authorities}

With an important Law of August 2015 (No.124/2015) the President of the Council Renzi, together with Minister for Public Administration Madia, have launched a general reform of Italian Public Administration. ${ }^{71}$

Law No.124/2015 (the so called "Law Madia”), which was widely glorified in the press as a revolutionary law, contains also an important provision concerning the topic of access to administrative documents and to public sector information.

According to its Art. 7, "without prejudice to the obligations of publication", freedom of information through the right of access to data and documents held by public authorities, also by electronic means, shall be granted "to anyone, regardless of ownership of a legally protected situation", except in cases of secrecy or prohibition of disclosure provided for by law and in the limits for the protection of public and private interests. The aim shall be to "promote widespread forms of control over the pursuit of official duties and the use of public resources". ${ }^{72}$

The provision of art. 7 certainly deserves a positive comment, because, as I already underlined in a previous papers of mine ${ }^{73}$, the current limitation contained in article 22, para $1 \mathrm{~b}$ (of Law No. 241 of 1990 on administrative procedure) of the right of access to administrative documents only to private parties having a "direct, concrete and existing interest corresponding to a legally protected situation that is linked to the document to which access is requested" 74 widely

\footnotetext{
68 See Art. 46 et seq. of Legislative Decree No. 33/2013, in the 2016 modified version.

${ }^{69}$ See Art. 15.2; Art. 26.3; Art. 39.3 of Legislative Decree No. 33/2013.

${ }^{70}$ Art. 5.1 of Legislative Decree No. 33/2013.

${ }^{71}$ Law of Aug. 7, 2015, n. 124, published in the Official Gazette of 08.13.2015 and entered into force on 28.8.2015.

${ }^{72}$ So Art. 7.1, letter h).

${ }^{73}$ See Galetta 2014, p. 231 et seq.

74 This limitation was introduced - first by way of interpretation of the existing provisions and then by the Italian legislator itself - in order avoid organizational problems to the public administration. And, therefore, in the name of a further and different goal, i.e.
} 
disappoints those who - like myself - believe that it is more consistent with the very meaning of the right of access to administrative documents to provide for a right of access connected to the need for informational-social control of the administrative action, regardless of the participation in a specific administrative procedure, or of the link with the adoption of an administrative decision in which the person is individually involved. ${ }^{75}$ And that, in this respect, the "journey towards transparency" outlined in Legislative Decree No. 150/2009 and in the original version of Decree No. 33/2013 was certainly not matching the desired change.

In order to implement the provision of art. 7 of "Law Madia"76, a Legislative Decree on transparency, dated 25 May 2016, n. 97, has recently been passed (hereafter the Italian FOIA). ${ }^{77}$

A part from the unchanged first paragraph of Art. $5^{78}$, Legislative Decree No. 97/2016 operates a radical modification of the provisions of Decree No. 33/2013 concerning public access (accesso civico). While, in fact, in the original provisions of Art. 5 of the Decree No. 33/2013 public access was limited only to those documents, information, or data which the public administration are obliged to publish and was meant (and designed) as a mere sanction in relation to the infringement of this 'obligation to publish', the Italian FOIA operates here a true revolution.

The new Art. 5.2 of the Decree states in fact that "In order to promote widespread forms of control on the pursuit of the institutional functions and on the use of public resources and to promote public participation in public debate, everyone has the right to access data and documents held by the public administrations, additional to those which are subject to publication in accordance with this decree". Public access to data and documents held by the public administrations is therefore to become the default rule. Restrictions are nonetheless possible when they appear necessary "for the protection of legally relevant public and private interests" (new Art. 5.2, last paragraph - see infra, para. 4.2).

It is a real 'paradigm shift': as the Italian FOIA designs now transparency as freedom of access to the data and documents held by public authorities guaranteed firstly, through a general public access to such data and documents (accesso civico); and, (only) secondly, through the publication of documents, information and data.

Public access (accesso civico) to data and documents held by public authorities is therefore to become the main instrument to achieve transparency and is not to remain relegated, as it was till now, in the role of a mere exception to the general rule stated in Art. 22 of Law No. 241/90. A rule which clearly designs access to documents as a peculiar right granted only to the stakeholders and with the sole purpose of ensuring the defense of a subjective legal position which could be adversely affected by the decision of a public authority.

The Italian FOIA states on the contrary that, in addition to the 'classical' right of access for

\footnotetext{
better efficiency and speed of the administrative action, which is also identified as a guiding principle in article 1 of Law No. 241/90 (quoted above, note No. 23).

${ }^{75}$ See Pastori 1986, p. 147 et seq.; D'Auria 1990, p. 111 et seq.; Alberti 1992, p. 122; Pubusa 1993, p. 134 et seq.; Romano Tassone 1995, p. 318 et seq.

${ }^{76}$ With Decision no. 251/2016 of November 25, 2016 (ECLI:IT:COST:2016:251) the Italian Constitutional Court has recently declared part of "Law Madia" to be unconstitutional. As a consequence, it has deprived of legal basis some of the legislative decrees adopted on its basis. This Decision does not affect, however, the FOIA Decree.

${ }^{77}$ Legislative Decree 25 May 2016, No. 97, Review and simplification of the provisions on prevention of corruption, openness and transparency, amending Law of 6 November 2012, No. 190 and Legislative Decree Of 14 March 14, 2013, No. 33, in accordance with Article 7 of Law of 7 August 2015, No. 124, on reorganization public administrations, published in the Official Gazette of 8 June 2016, No. 132.

${ }^{78}$ Public access to documents, information, or data for which Legislative Decree No. 33/2013 provides a disclosure obligation and just in case of failure to publish them. See supra, at the end of para. 3.3.
} 
stakeholders, provided for in Law No 241/90 (and which remains totally unchanged) ${ }^{79}$, according to its provisions a general public access (accesso civico) to data and documents held by public authorities shall be granted for the future. Indeed, according to Art. 6 of the Italian FOIA an applicant which requests public access does not need to possess a so called "qualified interest" and does not require any motivation. The application may be transmitted electronically and the release of information or documents in electronic or printed form is free, except for the reimbursement of the cost actually incurred and documented by the administration for the reproduction of material supports.

\subsection{Restrictions to public access and the role of the Anti-Corruption Authority}

This new, extended right to public access provided for by the Italian FOIA is, anyhow, by no means designed as an unlimited right. On the contrary, it is surrounded by a vast number of possible restrictions , aimed at protecting a wide number of public and private interests.

Alongside the 'classical' access restrictions, aimed at protecting public interests such as the ones relating to public safety and public order, national security, defense and military matters, international relations, policy, financial and economic stability of the State, investigations on crimes and their prosecution, inspections, there is also a rather long list of other possible restrictions concerning the protection of private interests. This includes the protection of personal data, secrecy of correspondence, as well as economic and business interests of a natural or legal person, including intellectual property, copyright and corporate secrets. ${ }^{80}$

It is a rather long list, including many different restrictions to public access which can concretely lead to access denial, to postponement of access or to limiting access only to certain parts of the requested documents. Even if they aim at protecting the core of legitimate public and private interests, they are too broadly defined ${ }^{81}$ and certainly need further concretization. ${ }^{82}$

In fact, in the absence of further concretization by the national legislator, it remains a discretionary decision of each single public administration to identify the actual content of such potentially unlimited restrictions to public access; or it will be up to the administrative courts to finally decide: if concrete restrictions to public access are challenged by their addressee. ${ }^{83}$

In order to address the above mentioned problem the FOIA legislator has in the end chosen to involve to the National Anti-Corruption Authority (hereafter ANAC) in the matter. Accordingly, Art. 5-bis of the Decree No. 33/2013 has been integrated with a sixth and last paragraph, according to which it will be up to the ANAC (in agreement with the Authority for the protection of personal data and after consultation with the Joint Conference of State, cities’ and local governments) to adopt guidelines (linee guida) ${ }^{84}$ containing 'operational indications' for the purpose of defining the exclusions and limitations to civic access.

\footnotetext{
${ }^{79}$ See to this regard Galetta 2016, para. 10, p. 15 s.

${ }^{80}$ See Art. 6 of the Italian FOIA.

${ }^{81}$ Galetta 2016, p. 9 et seq.

${ }^{82}$ Cf. Opinion of the Italian Council of State n. 515/2016, at: http://giustizia-amministrativa.it, p. 85 et seq. (Consultative Section for Normative Acts, 18 February 2016, No. 515).

${ }^{83} \mathrm{Up}$ to now the most delicate issue regarding accessibility of documents has concerned the relationship between the right of access and privacy protection and the Italian administrative courts that took a rather wavering position on the issue of the actual balance between access and privacy. See eg. Italian Council of State, V, 28 September 2007, No. 4999.

84 There is at present a great debate in Italian academic literature - involving also the Council of State in its advisory role - regarding the legal nature of guidelines adopted by an Independent Agency such as the National Anti-Corruption Authority. See to this regard the opinion delivered by the Italian Council of State on the scheme of the Public Contracts Code (opinion of 1 April 2016, No. 855, at: http://www.giustizia-amministrativa.it).
} 
Doubts arise about the appropriateness of entrusting also this competence to an Independent Agency such as ANAC, whose aim and nature is that of working as an 'anticorruption watchdog'. In fact, the choice made by the Italian legislator to this regard is based on the questionable assumption, that it is possible to identify a clear and unambiguous link between public access, transparency and combating corruption.

\section{Conclusions}

The adoption of an 'Italian FOIA' has been a manifesto commitment of the Renzi Government since the very beginning. On the day of its definitive approval the Minister for Simplification and Public Administration, Marianna Madia, gloriously stated as follows: "We have kept that promise. With the decree implementing the public administration reform, finally approved, Italy has adopted a law on the Freedom of Information Act model. Citizens have now the right to know data and documents held by the public administration, even without possessing a direct interest”. ${ }^{85}$

These are, in the opinion expressed by Minister Madia, the central points of the Italian FOIA:

1) requesting a document will be free of charge;

2) an administration that refuses to issue a document will have to motivate its refusal in a clear manner;

3) the citizen who has been refused by an administration to release information will be able to contact the transparency and anticorruption officer (responsabile della prevenzione della corruzione e della trasparenza) or the ombudsman and, in any case, to appeal to the competent Regional Administrative Tribunal (TAR).

An important criticism addressed to the Italian FOIA concerns the choice made by the Italian legislator, to move away from the idea of transparency understood just as an "Open Data Policy" (with a pro-active-disclosure-of-information approach), in order to embrace the public access model (the transparency-on-request approach). Thus, while confirming the obligation of public administrations to publish a certain amount of documents and data on their institutional websites $^{86}$, the Italian legislator opts, with the FOIA, for transparency understood as free-access-onrequest to data and documents held by public administrations.

Nonetheless, in my opinion this choice made by the Italian FOIA is a very good one, as it allows, on one hand, to avoid the risk of generating "opacity for confusion" rather than transparency ${ }^{87}$; and, on the other hand, it minimizes the risk of neglecting data protection, thus assuring also full compliance with the provisions of the new EU General Data Protection Regulation. ${ }^{88}$

To this regard, the existence of a real risk of detachment of the Italian Open Data Policy from the principles of protection of personal data was, in the contrary, clearly underlined by the

\footnotetext{
${ }^{85}$ See at: http://www.funzionepubblica.gov.it/articolo/riforma-della-pa/16-05-2016/foia-e-trasparenza-ora-e-legge.

${ }^{86}$ To this regard the Italian FOIA introduces also a rationalisation, by reducing excessive burdensome obligations to publish. See Galetta 2016, p. 17.

${ }^{87}$ See Carloni 2009, p. 806.

${ }^{88}$ Regulation (EU) 2016/679 of the European Parliament and of the Council of 27 April 2016 on the protection of natural persons with regard to the processing of personal data and on the free movement of such data (and repealing Directive 95/46/EC).
} 
Italian Data Protection Supervisor - at the time when this was still in its draft form - in its opinion released on the first version of Legislative Decree No. 33/2013. ${ }^{89}$

As a matter of fact, while transparency of the Public Administration is certainly an important issue for modern democracies, it still cannot be understood as a value in itself and its consistency with other founding values, such as privacy and data protection, has to be guaranteed at all times ${ }^{90}$. Furthermore, if the ultimate reason for national transparency policies is to ensure accountability of the Public Administration, the extent to which transparency, understood as a mere Open Data Policy, can actually deliver on its revolutionary potential has also to be called into question. ${ }^{91}$

So that, to conclude, the new direction in which the 'Italian journey' towards transparency has recently moved towards is likely to be the right one. From a very restrictive regime of access to administrative documents (the one designed by Law No. 241/90, which is however still applicable for those documents and data which are excluded from public access) - lately accompanied by a rather demagogical obligation imposed on public administrations to disclose a set of information in the context of so-called open data policies ${ }^{92}$ - Italy has namely moved forth to the hoped-for ${ }^{93}$ public access to data and documents held by public administrations: which, in my opinion, is the most correct way to implement the principle of transparency!

The more so since, to do it the other way round - i.e. by obliging public administrations to publish an increasingly large amount of incomprehensible and, in themselves, meaningless documents and data - has in fact very little to do with making information not only downloadable to citizens, but also useable and meaningful. ${ }^{94}$

\section{Reference list}

Agrifoglio, S. (1990). La trasparenza dell'azione amministrativa e il principio del contraddittorio: tra procedimento e processo. Diritto Processuale Amministrativo, 1, 46-67.

Alberti, M. (1992). L'accesso ai documenti amministrativi. In Alberti M. et al. (Eds.), Lezioni sul procedimento amministrativo (pp. 126-146). Torino: Giappichelli.

Allegretti, U. (1984). Pubblica amministrazione ed ordinamento democratico. Il Foro Italiano, 1984, 7-8, 205- 220.

Arena, G. (1984). Il segreto amministrativo. Profili storici e sistematici. Padova: CEDAM.

Arena, G. (1996). Trasparenza amministrativa e democrazia. In G. Berti \& G. De Martin (Eds.), Gli istituti della democrazia amministrativa (pp. 13-27). Milano: Giuffrè.

Arena, G. (2008). Le diverse finalità della trasparenza amministrativa. In F. Merloni (Ed.), La trasparenza amministrativa (pp. 29-44). Milano: Giuffré.

Arena, G. (1995). Trasparenza. Enciclopedia giuridica Treccani, update vol. IV (pp. 1-13). Roma: Treccani.

Arena, G. (1991). L'accesso ai documenti amministrativi. Bologna: Il Mulino.

Barile, P. (1987). Democrazia e segreto. Quaderni costituzionali, 1, 29-50.

Bonomo, A. (2012). Informazione e pubbliche amministrazioni. Dall'accesso ai documenti alla disponibilità delle informazioni. Bari: Cacucci Editore.

Bottino, G. (2014). Il nuovo articolo 97 della Costituzione. Rivista Trimestrale di Diritto Pubblico, 3, 691-719.

Brancasi, A (2012). L'introduzione del principio del c.d. pareggio di bilancio: un esempio di revisione affrettata della Costituzione. Quaderni costituzionali, 1, 108-111.

Buttarelli, G. (1997). Banche dati e tutela della riservatezza. La Privacy nella Società dell'Informazione. Milano: Giuffré.

Butti, G., Butti, L. (1991). Il «diritto di accesso» alle informazioni ambientali disponibili presso la pubblica amministrazione. Rivista giuridica dell'ambiente, 3, 461-468.

Canaparo, P. (2014). La via italiana alla trasparenza pubblica: Il diritto di informazione indifferenziato e il ruolo proattivo delle pubbliche amministrazioni. Federalismi.it, 4, 1-60.

Caringella, F., \& Garofoli, R., \& Sempreviva, M.T. (2007). L'accesso ai documenti amministrativi. Milano: Giuffré.

\footnotetext{
${ }^{89}$ Opinion of the Italian DPS No. 49 of 7 February 2013, doc web. No. 2243168.

${ }^{90}$ See further Galetta, 2015, p. 17 et seq.

${ }^{91}$ See also Galetta 2014, p. 6.

${ }^{92}$ On this point, see specifically Patroni Griffi 2013, para 2.

${ }^{93}$ See Galetta 2014, p. 234.

${ }^{94}$ See Canaparo 2014, para 10.; Napolitano 2005.
} 
3, 779-812.

Carloni, E. (2009). La "casa di vetro" e le riforme. Modelli e paradossi della trasparenza amministrativa. Diritto pubblico,

Carloni, E. (2012). La trasparenza (totale) delle pubbliche amministrazioni come servizio. Munus, 1, 179-198.

Carullo, A. (1998). La trasparenza nelle amministrazioni locali. Per una nuova legge comunale e provinciale. Bologna: Il

Mulino.

Chieppa, R. (1994). La trasparenza come regola della pubblica amministrazione. Diritto dell'Economia, 3, 613-625.

Clarich, M. (1996). Diritto d'accesso e tutela della riservatezza: regole sostanziali e tutela processuale. Diritto processuale amministrativo, 3, 430-458.

Cocco, G.F. (1980). I segreti di informazione e di sicurezza nell'ordinamento italiano, Padova: CEDAM.

Cuocolo, F.(1995). Commento all'articolo 22. In V. Italia \& M. Bassani (Eds.), Procedimento amministrativo e diritto di accesso ai documenti (Legge 7 agosto 1990, n. 241 e regolamenti di attuazione), 2nd ed. (pp. 527-545). Milano: Giuffré.

D'Auria, G. (1990). Trasparenze e segreti nell'Amministrazione italiana. Politica del diritto,1, 93-121.

De Cesaris A. (1991). Informazione ambientale e accesso ai documenti amministrativi. Rivista trimestrale di diritto pubblico, 3, 851-861.

Ferrari, G.F. (2008). Italian Public Law. Milano: Giuffré.

Figorilli F. (1995). Il contraddittorio nel giudizio speciale sul diritto di accesso. Diritto processuale amministrativo, 3, 584-

607.

Galetta, D.-U. (2006). Transparency and Administrative Governance in European Law. In M.P. Chiti (Ed.), General Principles of Administrative Action (153-181). Bologna: Bononia University Press.

Galetta, D.-U. (2012). La Ley Italiana 241/90 de Procedimiento Administrativo, in P. Aberastury/ H-J. Blanke (a cura di), Tendencias actuales del procedimiento administrativo en Latino América y Europa, Editorial Universitaria de Buenos Aires (EUDEBA), Buenos Aires e Fundación Konrad Adenauer, Oficina México, México, 2012, pp. 231-268

Galetta, D.-U. (2014). Alcuni recenti sviluppi del diritto amministrativo italiano (fra riforme costituzionali e sviluppi della società civile). Giustizia amministrativa (at http://www.giustamm.it), XI(June), 1-6.

Galetta, D.-U. (2014). Transparency and Access to Public Sector Information In Italy: a Proper Revolution? Italian Journal of Public Law, 6, 212-240.

Galetta, D.-U., Ibler, M. (2015). Decisioni amministrative "multipolari” e problematiche connesse: la libertà di informazione e il diritto alla riservatezza in una prospettiva di diritto comparato (Italia- Germania). Federalismi.it, 9, 1-29.

Galetta, D.-U. (2016). Accesso civico e trasparenza della Pubblica Amministrazione alla luce delle (previste) modifiche alle disposizioni del Decreto Legislativo n. 33/2013. Federalismi.it, 5, 2-19.

Galetta, D.-U. (2016). La trasparenza, per un nuovo rapporto tra cittadino e Pubblica Amministrazione: un'analisi storicoevolutiva in una prospettiva di diritto comparato ed europeo. Rivista italiana di diritto pubblico comunitario, 5.

Galetta, D.-U. (2016). The Italian Freedom of Information Act 2016 (why transparency-on-request is a better solution). Italian Journal of Public Law (at http://www.ijpl.eu).

Gallo C.E., \& Foà S. (2000). Accesso agli atti amministrativi. Digesto delle discipline pubblicistiche, update 2000 (1 - 27). Torino: UTET.

Leonardi, R. (2012). Il diritto di accesso ai documenti amministrativi: a proposito dei soggetti attivi per un'azione amministrativa trasparente, ma non troppo. Il Foro amministrativo T.A.R, 6, 2155-2182.

Losano, M.G. (2008). Trasparenza o privacy? Due recenti polemiche italiane. Diritto dell'Informazione e dell'Informatica, 4-5, 471-486.

Manganaro, F. , L'evoluzione del principio di trasparenza amministrativa. http://www.astrid-online.it/Malamminis/Note-econ/Manganaro_F_L-evoluzione-del-principio-di-trasparenza-amministrativa_pross_pubb_nov09.pdf. Accessed 10 June 2014.

Marrama, R. (1989). La pubblica amministrazione tra trasparenza e riservatezza nell'organizzazione e nel procedimento amministrativo. Diritto processuale amministrativo, 3, 416-452.

Massera, A. (2011). I criteri di economicità, efficacia ed efficienza, in M.A. Sandulli (Ed), Codice dell'azione amministrativa (pp. 22-82). Milano: Giuffré.

Mazzarolli, L. (1998). L'accesso ai documenti amministrativi. Profili sostanziali. Padova: CEDAM.

Merloni, F., \& Arena, G. et. al. (Eds.) (2008), La trasparenza amministrativa. Milano: Giuffré.

Merloni F., \& Arena, G. (2008). La trasparenza amministrativa. Milano: Giuffré.

Merloni, F. (2008). Trasparenza delle istituzioni e principio democratico. In F. Merloni, \& G. Arena (Eds.), La trasparenza amministrativa. Milano: Giuffré.

Merloni. F. (2013). La trasparenza come strumento di lotta alla corruzione tra legge n. 190 del 2012 e d. lgs. n. 33 del 2013. In B. Ponti (Ed.), La Trasparenza amministrativa dopo il d.lgs. 14 marzo 2013, n.33. Rimini: Maggioli.

Morbidelli, G. (2005). Il procedimento amministrativo. In L. Mazzarolli et al. (Eds.), Diritto amministrativo, vol. I. Bologna: Monduzzi.

Napolitano, G. (2005). L'attività informativa della pubblica amministrazione: 'less is better', in F. Manganaro, \& A. Romano Tassone (Eds.), I nuovi diritti di cittadinanza: il diritto d'informazione. Torino: Giappichelli.

Nigro, M. (1989). Il procedimento amministrativo fra inerzia legislativa e trasformazioni dell'amministrazione (a proposito di un recente disegno di legge). Diritto processuale amministrativo, 1, 5-24.

Occhiena M. (1998). Diritto di accesso, atti di diritto privato e tutela della riservatezza dopo la legge sulla privacy (il diritto di accesso e la riforma dell'organizzazione della p.a.). Diritto processuale amministrativo, 2, 377-418. 
Occhiena, M. (2006). I poteri della Commissione per l'accesso ai documenti amministrativi: in particolare, la funzione giustiziale ex L. n. 241/1990 e D.P.R. n. 184/2006, Giustizia amministrativa, 6, 1242-1252.

Occhiena, M. (2008). Necessaria riforma del diritto di accesso: diffusione e accesso telematico alle informazioni amministrative. Il diritto dell'economia, 1, 177-207.

Occhiena, M. (2012). I principi di pubblicità e trasparenza. in M. Renna, F. Saitta (Eds.), Studi sui principi del diritto amministrativo (141-148). Milano: Giuffré.

Pastori, G. (1986). Il diritto d'accesso ai documenti amministrativi in Italia. Amministrare, 1, 147-170.

Patrito, P., Pavoni, F (2012). La disciplina del riutilizzo dei dati pubblici dal punto di vista del diritto amministrativo: prime riflessioni. Il Diritto dell'Informazione, 87-109.

Patroni Griffi, F. (1992). Un contributo alla trasparenza dell'azione amministrativa: partecipazione procedimentale e accesso agli atti (legge 7 agosto 1990, n. 241). Diritto processuale amministrativo, 1, 56-72.

Patroni Griffi, F. (2013). La trasparenza della pubblica amministrazione tra accessibilità totale e riservatezza. Federalismi.it (at http://www.federalismi.it), 8, 1-12.

Perini, A. (1996). L'autonomia del diritto di accesso in giudizio. Diritto processuale amministrativo, 1, 107-120.

Perini, A. (1997). Il diritto di accesso e la tutela della riservatezza nelle amministrazioni locali. Rivista Amministrativa della Repubblica Italiana, 12, 1147-1163.

Cacucci.

Pignataro, S. (2012). Il principio costituzionale del "buon andamento" e la riforma della pubblica amministrazione. Bari:

Ponti, B. (2008). Il regime dei dati pubblici. Esperienza europee e ordinamento nazionale. Rimini: Maggioli.

Ponti, B. (2011). Open Data and Transparency: A Paradigm Shift. Informatica e Diritto, 1-2, 305-320.

Ponti, B. ( 2013). La trasparenza amministrativa dopo il d.lgs.14 marzo 2013, n. 33. Rimini: Maggioli.

Pubusa, A. (1993). L'attività amministrativa in trasformazione. Studi sulla l. 7 agosto 1990, n. 241. Torino: Giappichelli.

Puliatti, P. (1997). Primi avvisi giurisprudenziali sul diritto di accesso ai documenti amministrativi. I Tribunali amministrativi regionali, 12, 497-501.

Raines, J. (2012-2013). The Digital Accountability and Transparency Act of 2011 (DATA): Using Open Data Principles to Revamp Spending Transparency Legislation. New York Law School Law Review, 57, 313-360

Ricciardi, M. (1993). Appunti sul segreto di Stato e principio di trasparenza. Politica del diritto, 1, 35-50.

Romano Tassone, A. (1995). A chi serve il diritto di accesso. Riflessioni su legittimazione e modalità di esercizio del diritto di accesso nella legge n. 241 del 1990. Diritto amministrativo, 317-340.

Romeo, G. (1999). Accesso ai documenti e riservatezza: rovescio e diritto di una medesima realtà. Il Foro amministrativo, 9(III), 435-444.

Salvatore, P. (1996). Trasparenza, dovere di comunicazione e tutela del segreto e della riservatezza. Il Consiglio di Stato, 11(2), 2019-2025.

Sandulli, M.A. (2000). Accesso alle notizie e ai documenti amministrativi. Enciclopedia del Diritto, update vol. IV (pp. 130). Milano: Giuffré.

Sandulli, A. (1998). La riduzione dei limiti all'accesso ai documenti amministrativi. Giornale di diritto amministrativo, 529-

537.

Santoro, P. (1992). Diritto di accesso partecipativo e diritto di accesso conoscitivo: posizioni soggettive ed effettività. Il Foro amministrativo, 7-8, 1799-1806.

Savino, M. (2013), La nuova disciplina della trasparenza amministrativa, in Giornale di diritto amministrativo, 8/9, 795-

805.

Scognamiglio, A. (1996). Il diritto di accesso nella disciplina della l. 7 agosto 1990 n. 241 e il problema della legittimazione. Rivista trimestrale di diritto pubblico, 1, 93-114.

Scognamiglio, A. (2005). Diritto di accesso e banche dati pubbliche. Il Foro Amministrativo - Consiglio di Stato, 2, 493-

502.

Selleri, B. (1989). Il diritto di accesso agli atti amministrativi tra tensione alla riforma e fedeltà alle strutture del sistema positivo. In La disciplina generale del procedimento amministrativo (Atti del XXXII Convegno di studi di scienza dell'amministrazione, Varenna-Villa Monastero, 18-20 settembre 1986). Milano: Giuffré.

Selleri, B. (1984). Il diritto di accesso agli atti del procedimento amministrativo. Napoli: Jovene.

Sorace, D. (2012). Diritto delle amministrazioni pubbliche. Una introduzione. Bologna: Il Mulino.

Spasiano, M.R. (2011). I principi di pubblicità, trasparenza e imparzialità. M.A. Sandulli (Ed.), Codice dell'azione amministrativa (pp. 83-95). Milano: Giuffré.

M.R. Spasiano \&, D. Corletto, \& M. Gola, \& D.U. Galetta et al. (Eds.) (2012). La Pubblica Amministrazione e il suo diritto. Bologna: Monduzzi Editoriale.

Truini, P. (1993). Diritto all'informazione e riservatezza. Rivista Amministrativa della Repubblica Italiana, 6-7, 799-803.

Villata, R. (1989). Interesse ad agire (Diritto processuale civile). Enciclopedia giuridica Treccani, vol. XVII. Roma: Treccani.

Villata, R. (1987). La trasparenza dell'azione amministrativa. Diritto Processuale Amministrativo, 4, 528-557.

Villata, R. (1989). La trasparenza dell'azione amministrativa. In La disciplina generale del procedimento amministrativo (Atti del XXXII Convegno di studi di scienza dell'amministrazione, Varenna-Villa Monastero, 18-20 settembre 1986). Milano: Giuffré. 
Villata, R. (1992). Riflessioni in tema di partecipazione al procedimento e legittimazione processuale. Diritto Processuale Amministrativo, 2, 171-205.

Virga, G. (1998). La partecipazione al procedimento amministrativo. Milano: Giuffré.

Volpe, F. (1991). Trasparenza e partecipazione nell'ordinamento delle autonomie locali. I Tribunali amministrativi regionali, 5-6, 253-265.

Ziller, J. (2014). Origines et retombées du principe de transparence du droit de l’Union européenne. In G. Guglielmi, E Zoller (Eds.), Démocratie, transparence et gouvernance citoyenne, Paris: Editions Panthéon-Assas.

Zito, A. (1996). Le pretese partecipative del privato nel procedimento amministrativo. Milano: Giuffré.

\section{List of Case-Law}

Court of First Instance, 17 June 1998, in Case T-174/95, Svenska Journalistförbunde v. Council

Italian Constitutional Court, 25 November 2016, No. 251

Italian Council of State, VI, 7 December 1993, No. 966

Italian Council of State, VI, 19 July 1994, No. 1243

Italian Council of State, IV, 26 November 1993, No. 1036

Italian Council of State, IV, 10 June 1996, No. 1024

Italian Council of State , V, 2 December 1998, No. 1725

Italian Council of State, plenary section, 22 April 1999, No. 4

Italian Council of State, plenary section, 24 June 1999, No. 16

Italian Council of State, VI, 5 March 2002, No. 1303

Italian Council of State, V, 18 March 2004, No. 1412

Italian Council of State, V, 28 September 2007, No. 4999

Italian Council of State, Consultative Section for Normative Acts, 18 February 2016, No. 515 